Gut, 1981, $22845-848$

\title{
Circulating immune complexes in patients with fulminant hepatic failure
}

\author{
J CANALESE, $R$ J WYKE, D VERGANI, A L W F EDDLESTON, \\ AND ROGER WILLIAMS \\ From the Liver Unit and Department of Immunology, King's College Hospital, London
}

SUMMARY Circulating immune complexes were found in 15 of 16 patients with fulminant hepatic failure due to viral hepatitis and all of six patients who had had halothane anaesthesia; however, they were found in only five of 32 patients with paracetamol-induced hepatic necrosis. The levels of circulating immune complexes were not related to the severity of the clinical course, development of renal failure, final outcome, or severity of hypocomplementaemia. All the patients had depressed reticuloendothelial function as assessed by the clearance of ${ }^{125} \mathrm{I}$ microaggregated albumin. These findings show that circulating immune complexes in fulminant hepatic failure are not simply a reflection of an immune response to liver antigens released as a result of the hepatic necrosis; nor are they a reflection of the failure of the reticuloendothelial system. This supports the view that circulating immune complexes are associated with immune mediated liver injury and may contribute to the process.

The mechanism responsible for the progression of some cases of acute viral hepatitis to fulminant hepatic failure is poorly understood. In fulminant hepatic failure due to hepatitis B virus the early appearance of antibody to hepatitis B surface antigen (HBsAg) and rapid disappearance of $\mathrm{HBsAg}$ from the serum, ${ }^{2}$ and the finding of immune complexes on direct electronmicroscopy, ${ }^{3}$ have led some authors to postulate that severe liver damage may follow the deposition of immune complexes in the liver sinusoids. ${ }^{2}$ Whether or not immune complexes play a part in other types of fulminant viral hepatitis or in drug-induced hepatic failure has not been investigated.

In this study we measured levels of circulating immune complexes in patients with fulminant viral hepatitis and in patients with fulminant hepatic failure after halothane anaesthesia or paracetamol overdose. The level of circulating immune complexes depends on a balance between formation and removal from the circulation by the reticuloendothelial system; ${ }^{4}$ changes in the latter were assessed by measuring the clearance from the circulation of iodinated microaggregated human albumin ( ${ }^{125}$ IMAA). ${ }^{5}$ As immune complexes consume complement and their deposition in the glomeruli of the kidney can cause renal failure, ${ }^{6}$ which is common in fulminant hepatic failure, ${ }^{7}$ serum

Received for publication 29 April 198 complement activity and renal function were also assessed to determine the immunological and clinical significance of the circulating immune complexes.

\section{Methods}

\section{PATIENTS}

Fifty-five patients with fulminant hepatic failure were studied ( 28 female, 27 male), aged from 14 to 67 years (median 28 years), all of whom had deteriorated to grade IV hepatic encephalopathy. ${ }^{8}$ Hepatic necrosis was attributed to paracetamol self-poisoning in 32 patients; viral type A in six (shown by the presence of the specific antibody with ELISA techniqueOrganon Teknika); hepatitis type B in three (shown by the presence of HBsAg with ELISA (Ausyme)); presumed non-A, non-B hepatitis in seven; and halothane-associated hepatitis in seven. All patients received full supportive care ${ }^{9}$ and daily periods of haemodialysis with a polyacrylonitrile membrane (Rhone Poulenc RP 6) and/or haemoperfusion with a Haemacol 100 column (Smith and Nephew Research Ltd) and added prostacyclin as platelet protective agent. ${ }^{10}$ The initial measurements were always made before such periods of temporary liver support.

MEASUREMENT OF IMMUNE COMPI.EXES AND COMPI.EMENT L.EVELS

Venous blood was allowed to clot for two hours at 
room temperature; serum was separated and was used either immediately or stored at $-70^{\circ} \mathrm{c}$ or $-196^{\circ} \mathrm{C}$ until time of assay. Samples were thawed only once. Levels of circulating immune complexes were measured by the $\mathrm{Cl}_{\mathrm{q}}$ binding assay according to the method of Zubler et al. " Normal range was calculated from the mean \pm 2 SD of values obtained from the sera of 25 blood donors.

Functional activities of total haemolytic complement $\left(\mathrm{CH}_{50}\right)$ and total alternative pathway were measured in 20 patients by haemolytic diffusion in agarose. $^{1213}$ Concentrations of immunoreactive C3 were determined by radial immunodiffusion against rabbit antiserum (kindly provided by Professor D K Peters). Results were expressed as a percentage of the activity of a control serum pool, derived from six healthy laboratory personnel, which was included as a standard in each plate.

\section{ASSESSMENT OF RETICULOENDOTHELIAL SYSTEM FUNCTION}

Microaggregated iodinated serum albumin ( ${ }^{125}$ IMAA) was prepared by the method of Iio and Wagner ${ }^{5}$ as previously reported. ${ }^{14}$ After an intravenous injection of sodium iodide to block radio-iodine uptake by the thyroid, ${ }^{125}$ IMAA, $5 \mathrm{mg} / \mathrm{kg}$ body weight was injected; $2 \mathrm{ml}$ blood samples were taken into EDTA anticoagulant $0,3,5,7,10,12,15$, and 20 minutes later. The plasma was separated immediately and the ${ }^{125} \mathrm{I}$ activity in a 0.5 $\mathrm{ml}$ aliquot was counted with a gamma counter (Hewlett Packard). The half life $(\mathrm{t} / 2)$ of clearance was calculated by plotting $\log _{10}$ counts per minute against time in minutes. Four normal volunteers acted as controls.

\section{Results}

Fifteen of the 16 patients with fulminant hepatic failure attributed to viral hepatitis had raised levels of circulating immune complexes, with a mean for the 16 patients of $33.6 \pm \mathrm{SD} 14.3 \%$, which was significantly (P $<0.01$, Wilcoxon's rank sum test) higher than the mean of $9 \cdot 6 \pm 3$ for controls (Figure). The raised level of circulating immune complexes in patients with viral hepatitis was not related to the type of viral hepatitis, to the severity of the clinical course, or final outcome. The six patients with halothane-associated hepatitis also had higher levels of circulating immune complexes than controls, with a mean of $31 \cdot 4 \pm \mathrm{SD}$ 14.5 , which was similar to that in patients with viral hepatitis (Figure). In contrast, 27 of the 32 patients with paracetamol overdose had normal levels, with a mean for the 32 patients of $13 \cdot 5 \pm$ SD $3 \cdot 4$. Five patients had raised levels; the two with the highest values had received transfusions of plasma protein fraction within the preceding 12 hours, and one of these two

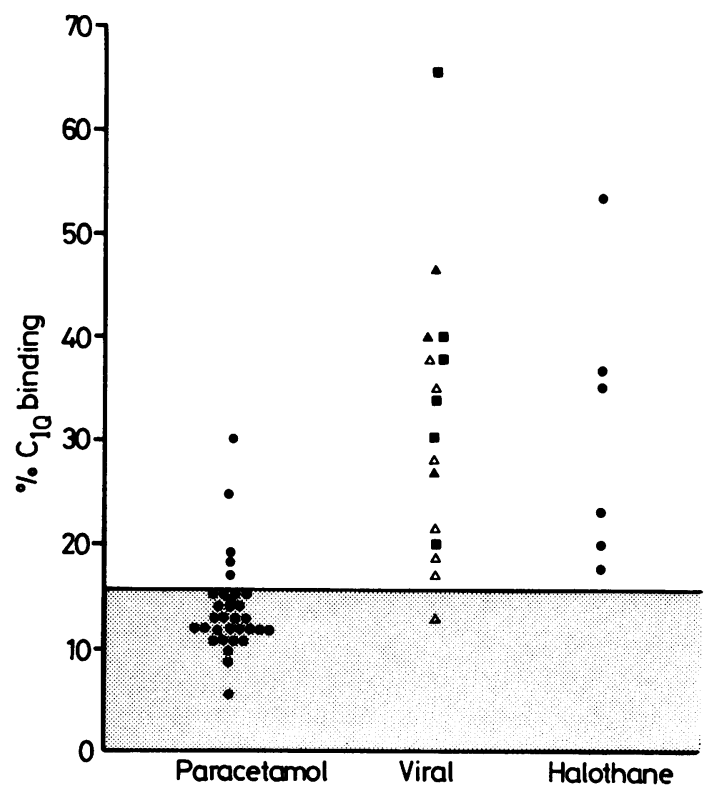

Figure Initial measurement of $\mathrm{Clq}$ binding activity in patients with fulminant hepatic failure. $\mathbf{\Delta}$ hepatitis $B$, hepatitis $A, \triangle$ presumed non- $A$, non- $B$. Dotted area: normal range mean $\pm 2 S D$.

patients also had an $E$. coli septicaemia. Similarly, the patient with the highest levels of immune complexes in the halothane-associated hepatitis group had pneumonia. Except for these three patients, no other patients in the series had evidence of bacterial infection or had received blood products before the first sample was taken. Serial studies of circulating immune complexes showed that, in patients with viral and halothane-associated hepatitis, levels remained raised. Similarly, in patients with paracetamol overdose, levels remained within the normal range unless complicated by the development of cultureproven bacterial infection or administration of blood products, which in three patients was associated with a mean increase of $220 \%$ of initial levels.

Nine patients had renal failure (creatinine $>350$ $\mu \mathrm{mol} / 1$ or urine output $\leq 300 \mathrm{ml} / 24 \mathrm{~h}$ ) during the study, and in 14 others it developed later. There was no difference in levels of circulating immune complexes between patients who did or did not develop renal failure, or in whom it had already developed.

\section{SERUM COMPI.EMENT AND RETICULOENDOTHEI.IAL} FUNCTION

The functional activity of the alternative and classical pathways $\left(\mathrm{CH}_{50}\right)$ of complement and levels of immunoreactive $\mathrm{C} 3$ were reduced in all 20 patients 
studied to a mean of less than $30 \%$ of the activity of the control serum pool (Table). The severity of the complement deficiency was similar in patients with viral hepatitis, halothane-associated hepatitis, and paracetamol overdose and there was no correlation between the level of serum complement and that of circulating immune complexes.

The plasma half-life $(\mathrm{t} / 2)$ of ${ }^{125}$ IMAA was prolonged in all 25 patients studied, ranging from 18 to 36 minutes compared with an upper limit of normal for controls of 15.6 (mean $+2 \mathrm{SD}$ ). There was no difference in the degree of prolongation of $t / 2$ between any of the patient groups; and no correlation was found between the $t / 2$ and either levels of circulating immune complexes or complement levels.

Table Serum complement expressed as percentage activity of control serum pool (mean $\pm S D$ )

\begin{tabular}{|c|c|c|c|c|}
\hline $\begin{array}{l}\text { Clinical } \\
\text { groups }\end{array}$ & $\begin{array}{l}\text { Number } \\
\text { of cases }\end{array}$ & $C 3$ & $\begin{array}{l}\text { Classical pathwa! } \\
\mathrm{CH}_{\mathrm{si}}\end{array}$ & $\begin{array}{l}\text { Total aliernative } \\
\text { pathway }\end{array}$ \\
\hline All cases & 20 & $25 \cdot 4 \pm 14 \cdot 5$ & $9 \cdot 3 \pm 13 \cdot 2$ & $23 \cdot 8 \pm 13 \cdot 1$ \\
\hline Paracetamol & 9 & $29 \cdot 3 \pm 16 \cdot 9$ & $18 \pm 15 \cdot 1$ & $26 \cdot 5 \pm 9 \cdot 8$ \\
\hline Viral hepatitis & 7 & $33 \pm 17 \cdot 5$ & $19 \cdot 2 \pm 13 \cdot 3$ & $23 \cdot 1 \pm 9 \cdot 6$ \\
\hline Halothane & 3 & 15.6 & $10 \cdot 6$ & $14 \cdot 4$ \\
\hline Controls & 30 & $103 \pm 18 \cdot 5$ & $108 \pm 19$ & $107 \pm 20$ \\
\hline
\end{tabular}

\section{Discussion}

As, with few exceptions, levels of circulating immune complexes were not raised in patients with paracetamol overdose it is unlikely that the increased levels in cases attributed to viral or halothane-associated fulminant hepatic failure are simply a reflection of the immune response to released liver antigens as a result of the hepatic necrosis. It is more likely that antibody, produced in response to specific antigens generated by the aetiological agent, complexes with the corresponding antigen released from the damaged liver cells. Specific immunological responses to neo-antigens occur in acute hepatitis $A$ and $B$ virus infections and are likely to accompany infection with non-A, non-B agent(s). Although the mechanism of halothaneassociated hepatic necrosis has been the subject of much debate, a recent study has shown that serum from most of these patients contains antibody to a neo-antigen formed on the surface of rabbit hepatocytes. ${ }^{15}$ The formation of this antigen is associated with the metabolic degradation of halothane via an oxidative pathway. ${ }^{16}$ This is the first time increased levels of circulating complexes have been reported in cases of fulminant halothane- associated hepatitis and is additional evidence in favour of an immunological mechanism. However, the finding of increased levels of circulating immune complexes in patients with fuminant viral and halothane-associated hepatitis may be only one aspect of a number of immunological aberrations in these two disorders and not necessarily an indication of an aetiological role for the immune complexes in the production of the liver damage.

In cases of paracetamol overdose, hepatic necrosis is dose dependent and is thought to be due to the formation of reactive intermediary metabolites. In these patients levels of circulating immune complexes were raised only in association with episodes of infection or tranfusion and it is likely that these complexes are manifestations of immune responses to bacterial antigens and altered plasma proteins, respectively. Methods of measurement of circulating immune complexes all have drawbacks, in particular the binding of Clq by DNA, bacterial lipopolysaccharide, and heparin which may produce eroneous results. However, with the technique of Zubler et al. $(1976)^{11}$ only heparin is a potential problem and, as each of our patient groups received similar amounts, this is unlikely to be a source of significant error. As sera from all the patient groups were handled in the same way with respect to collection, separation, and storage, variations of aggregation of immunoglobulin or formation of cryoprecipitates are unlikely to account for the difference in Clq binding activity between the different patient groups.

The severe impairment of the function of the reticuloendothelial system shown by the prolonged clearance from the circulation of ${ }^{125}$ IMAA in all the patients with fulminant hepatic failure, irrespective of aetiology, has several important implications. Such a defect would impair the clearance from the circulation of circulating immune complexes, bacteria, and endotoxins, which has been shown in animal studies to contribute to liver damage. ${ }^{17}$ Both parenchymal and non-parenchymal liver cells are thought to be the site of synthesis of many complement factors, and with massive liver cell necrosis the production of these will be reduced. This almost certainly explains the low levels of complement found in all patients studied, including those in whom circulating immune complexes were not increased. As complement turnover studies cannot be performed in vivo, because of the short duration of illness and unstable clinical course, the importance of complement consumption cannot be assessed. Serum complement deficiency may contribute to the increased levels of circulating immune complexes, as there is evidence that the alternative pathway of complement is involved in the solubilisation of immune complexes. ${ }^{18}$

Renal failure has been attributed to immune 
complex deposition in some cases of acute viral hepatitis, especially type $B$, but in our patients there was no correlation between levels of circulating immune complexes and the occurrence of renal failure. Furthermore, renal failure occurred with equal frequency in cases of fulminant hepatic failure attributed to both paracetamol overdose or viral hepatitis, although levels of circulating immune complexes were normal in the former. It is more likely that the impairment of the reticuloendothelial system predisposes to the development of systemic endotoxaemia with consequent renal vasoconstriction and renal failure. ${ }^{19}$

We are grateful to Immuno Ltd and the MRC for financial support and to Dr E N Wardle for valuable advice.

\section{References}

'Trepo CG, Robert D, Motin J, Prince AM. Hepatitis B antigen ( $\mathrm{HBs} \mathrm{Ag}$ ) and/or antibodies (anti $\mathrm{HBs}$ and anti $\mathrm{HBc}$ ) in fulminant hepatitis: pathogenic and prognostic significance. Gut 1976: 17:10-13.

${ }^{2}$ Woolf IL et al. Enhanced HBsAb production in pathogenesis of fulminant viral hepatitis. Br Med J 1976; 2:669-71.

${ }^{3}$ Almeida JP, Watersorson AP. The morphology of virus antibody ineraction. Adv Virus Res 1969; 15:307-8.

${ }^{4}$ Mannik M, Haakenstad AO, Arend WP. The fate and detection of circulating immune complexes. In: Brent L, Holborow J, eds. Progress in immunology II. Vol. 5. Amsterdam: North Holland, 1974: 91-101.

${ }^{5}$ Iio M, Wagner HN. Studies in the reticuloendothelial system (RES). (i) Measurement of the phagocytic capacity of the RES in man and dog. J Clin Invest 1963; 42:417-26. ${ }^{6}$ Coombes BB et al. Glomerulonephritis with deposition of Australia antigen-antibody complexes in glomerular basement membrane. Lancet 1971; 2:234-7.
${ }^{7}$ Wilkinson SP, Blendis LM, Williams R. Frequency and type of renal and electrolyte disorders in fulminant hepatic failure. $\mathrm{Br} \mathrm{Med} \mathrm{J} \mathrm{1974;} \mathrm{1:186-9.}$

${ }^{8}$ Trey C, Davidson CS. The management of fulminant hepatic failure. In: Popper H, Schaffer E, eds. Progress in liver diseases. Vol. 3. New York: Grune and Stratton, 1970: 282-98.

${ }^{9}$ Trewby PN, Williams R. In: Hanson GC, Wright, PL eds. Medical management of the critically ill. New York: Academic Press, 1978: 99-115.

${ }^{10}$ Gimson AES et al. Prostacyclin to prevent platelet activation during charcoal haemoperfusion in fulminant hepatic failure. Lancet $1980 ; 1: 173-5$.

"Zubler RH, Lange G, Lambert PH. Detection of immune complexes in untreated sera by a modified $\mathrm{C}_{14}$ binding assay. $J$ Immunol 1976; 116:232-5.

${ }^{12}$ Lachman PJ, Hobart NJ, Aston WP. Complement technology. In: Weir DM, ed. Handbook of experimental immunology. Oxford: Blackwell, 1973: 7-12.

${ }^{13}$ Martin A, Lachman PJ, Halbwachs L, Hobart MJ. Haemolytic diffusion plate assays for factor $B$ and $D$ of the alternative pathway of complement activation. Immunochemistry: 1976; 13:317-24.

${ }^{14}$ Drivas G, Uldall PR, Wardle EN. Reticuloendothelial function in renal allograft patients. $\mathrm{Br}$ Med J 1975; 3:743-5.

${ }^{15}$ Vergani D et al. Antibodies to the surface of halothanealtered rabbit hepatocytes in patients with severe halothane associated hepatitis. N Engl J Med 1980; 303:66-71.

${ }^{16}$ Neuberger JM, Mieli-Vergani G, Tredger M. Davis M, Williams R. Oxidative metabolism of halothane in the immunopathogenesis of the associated liver damage. Gut 1980; 21:A467.

${ }^{17}$ Grun M, Liehr H, Rasenack U. Significance of endotoxaemia 'galactosamine-hepatitis' in rats. Acta Hepatogastroenterol 1977; 24:64-81.

${ }^{18}$ Czop J, Nussenzweig V. Studies of the mechanism of solubilisation of immune precipitates by serum. J Exp Med 1976; 143:615-30.

${ }^{19}$ Wilkinson SP, Arroyo V, Gazzard BG, Moodie H, Williams R. Relation of renal impairment and haemorrhagic diathesis to endotoxaemia in fulminant hepatic failure. Lancet 1974; 1:521-24. 